\title{
Methaqualone Measurement
}

National Cancer Institute

\section{Source}

National Cancer Institute. Methaqualone Measurement. NCI Thesaurus. Code C74882.

The determination of the amount of methaqualone present in a sample. 